\title{
Editorial 44
}

\author{
Eric Scerri
}

Published online: 5 June 2013

(C) Springer Science+Business Media Dordrecht 2013

The issue in front of you is part special issue part varia issue.

The special issue is based on the 15th ISPC meeting held in Bogota, Colombia in the summer of 2011 and edited by Guillermo Restrepo who was also the organizer of the session.

It contains articles by the distinguished philosopher Rom Harré discussing mereology, a topic that he has written on widely. It also contains a paper by the equally distinguished historian of chemistry, Alan Rocke, who joined us for the first time at this meeting. Rocke writes about his beloved nineteenth century chemistry on which he has published many classic articles and books.

Other contributions from the same meeting include José Antonio Chamizo from UNAM in Mexico on what he calls 'technochemistry', and Farzad Mahootian from New York who revisits the theme of 'element-hood' that has been the subject of many a paper in this journal. The issue closes with an article by Restrepo himself on the mathematization of chemistry.

Among the varia papers you will find Peter Nelson on the electronic basis for the periodic table, Amihud Gilead on quasi-crystals, Alex Manafu on internal realism and Geoffrey Rayner-Canham on patterns in the periodic table. Last but not least, two book reviews by the irrepressible George Kauffan, surely the Asimov of the world of chemistry.

The next ISPC meeting, the 17th, will take place in Montevideo, Uruguay thanks to the organizational efforts of Lucia Lewowicz between July 31 and August 3rd, 2013.

E. Scerri $(\bowtie)$

Department of Chemistry and Biochemistry, UCLA, Los Angeles, CA 90095, USA

e-mail: scerri@chem.ucla.edu 